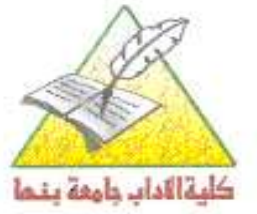

مجلة كلية الآداب

بلة دورية علمية محكمة

نصف سـنوية

المدد السابع والالربمون

ابريلا r.v 


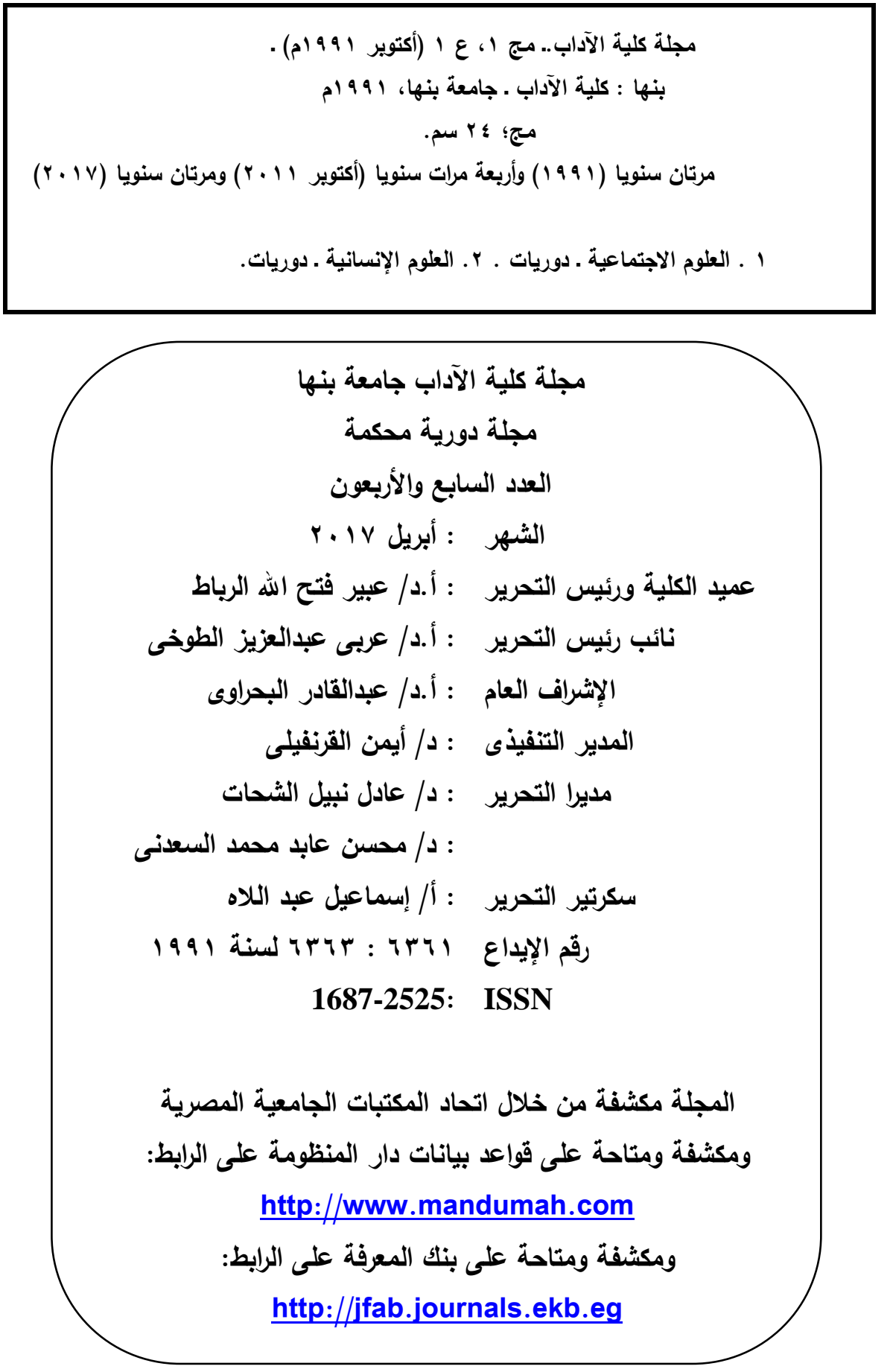




\section{هينّة تحرير الطجلة}

$$
\begin{aligned}
& \text { عميد الكلية ورئيس مجلس الإدارة } \\
& \text { ورئيس التحرير } \\
& \text { أ.د/عبرفتحالهالراط } \\
& \text { نائب رئيس التحرير }
\end{aligned}
$$

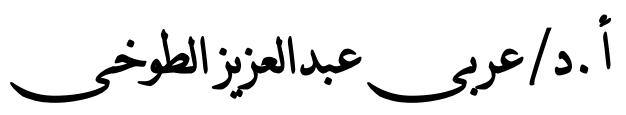

$$
\begin{aligned}
& \text { الإشراف العام } \\
& \text { أ .د /عبدالقادر البحراوى } \\
& \text { المدير التنفيذى }
\end{aligned}
$$

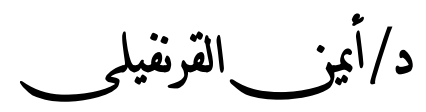

$$
\begin{aligned}
& \text { مدير تحرير المجلة } \\
& \text { د/عادلنبيل } \\
& \text { مدير تحرير المجلة }
\end{aligned}
$$

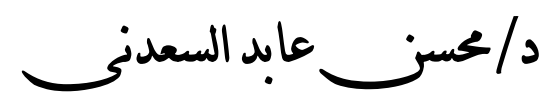

$$
\begin{aligned}
& \text { سكرتير التحرير } \\
& \text { آ/إسماعيل عبد اللاه }
\end{aligned}
$$




\title{
Style and Cognition in Dan Brown's The Da Vinci Code
}

\author{
A Paper Submitted \\ By
}

Amira Abd El-Aziz Abou Alam

English Language Instructor

at Banha University

Faculty of Arts 


\title{
Style and Cognition in Dan Brown's
}

\section{The Da Vinci Code}

\begin{abstract}
This research aims at providing a detailed description by way of presenting an illustrative analysis of the cognitive stylistic features of Dan Brown's The Da Vinci Code (2003). The significant target of the study is to manifest the aesthetic characteristics through connecting the text- world to the reader's world, where both of the reader and the writer become active. It also explains how the fictional work manages to extend the reader's mental space so as to be able to taste and interpret the literary works. The investigation adopts a qualitative method. The aim of the qualitative analysis is a complete and detailed description of examples. The research is tackled within Gavins' (2007) text world theory. On the basis of the proposed theory, a comprehensive analysis of the novel in terms of discourse-world level, text- world level, and sub-world level is to be carried out. Analyzing these worlds contributes to the narration. It also explains the conflict between the novel's characters which is a result of their different mental spaces or worlds, and how this diversity becomes responsible for the emergence of smaller worlds inside the main world. The investigation includes different types of discourse like face-to-face conversations, narrative structures, description, visions, and expression of feelings and emotions.
\end{abstract}




\section{Introduction}

The Da Vinci Code is classified by critics as detective fiction. It contains these unmistakable elements which qualify it to be a suspense novel. There is always a character who investigates in order to unlock the circumstances of a crime, where there are witnesses, victims, chases, and puzzles. According to Rezpka and Horsley (2010), it is difficult to introduce a clear definition for detective fiction because it is a "mish-mash of autobiography, plagiarism, ghost-writing, fable, and picaresque braggadocio"(p. 2). It is known that detective fiction begins with Edgar Allan Poe, when he writes The Murders in the Rue Morgue in 1841, but the origin of the genre, as Sayers (1992) proposes, dates back to four stories which are two Old Testament stories from the book of Daniel, one story from Herodotus, dating from the fifth century $\mathrm{BC}$, and one story drawn from Hercules myth. "But, whereas the tale of horror has flourished in practically every age and country, the detective story has had a spasmodic history, appearing here and there in faint, tentative sketches and episodes"(Sayers, 1992, p. 72).

According to Scaggs (2005), there is a relation between detective fiction and Gothic novel. Gothic novel is characterized by bringing the past back into the present, and this reflects the social tension between pre-enlightenment and post-enlightenment (Enlightenment appeared in Europe in the 18th century and led to the French Revolution in 1789). Botting (2001) observes that the Gothic novel celebrates murder, betrayal, and bad deeds, so it "appeared to celebrate criminal behavior"(p. 6). Gothic novels are marked by old castles, evil aristocrats, and ghosts. This pulls the pre-enlightenment past to be present in the postenlightenment era and consequently gives rise to social disorder. 
In Britain, the Golden Age of detective fiction begins with the publication of Agatha Christie's first novel, The Mysterious Affair at Styles in 1920 and ends in the wake of the Second World War. Scaggs (2005) claims that the influence of Christie on the genre of detective fiction is excessive, where she introduces the country-house murder which is very close to the whodunit mode. The whodunit mode is a classical, British form, in contrast to the American hard-boiled mode. It presents an ingenious plotting which leads the reader to discover whodunit before the novel reveals it. It is a sort of appealing to reason and logic. Hard-boiled fiction, on the contrary, concentrates on the character of the detective, where the plot is marked by violence and betrayal. "Such gangster stories, in which an individual form a disadvantaged background becomes rich and powerful from a life of crime...in an increasingly aggressive capitalist society"(Scaggs, 2005, p. 29).

Dan Brown is one of the most American acknowledged thriller fiction writers of his age. His novels have been translated into 52 languages. He was born in 1964 in Exeter, New Hampshire. He studied art, history, and writing. After his marriage, he became an English teacher. In 1996, Brown gave up teaching to become a fulltime writer. "For him, writing is a discipline, much like playing a musical instrument; it requires constant practice for this reason he writes seven days a week"(Lattman, 2006). He wrote Digital Fortress in 1998. It is a thriller set in Spain. He also wrote Deception Point before achieving the big success by publishing The Da Vinci Code. Rogak (2005) states:

In any case, on subsequent reprints of the book, the ambigram title on the cover was replaced with a more traditionally layout and design, though later on, as the runaway success of The Da Vinci Code accelerated, Dan Brown's name on the cover of Angels \& Demons and his other two novels grew larger, eventually becoming the same size as the 
Style and Cognition in Dan Brown's The Da Vinci Code Dr. Amira Abou Alam

titles. This is a sign that an author has become a brand name-or, in the parlance of the publishing industry, a 'franchise' author. ( p. 72)

The Da Vinci Code was published in 2003 as a mystery detective novel. It explores a religious history, pretending that the Merovingian kings of France were descended from the bloodline of Jesus Christ and Mary Magdalene. This is considered, by critics, an attack on the Roman Catholic Church. Haye (2009) states:

Chief among such modern-day-pro-Gnostic tomes is The Da Vinci Code by author Dan Brown, which spent more than two years on the New York Times best-seller list. Its revisionist claims include the assertion that Jesus was married and that His divinity was a concept invented by the Emperor Constantine in AD 325. When confronted with proof of the innumerable historical errors contained in the book, brown defenders sidestep the issue by stating that The Da Vinci Code is a work of fiction. ( p. 17)

In spite of this, the novel became a worldwide bestseller which sold 80 million copies and which has been translated into 44 languages. Also, a lot of criticism has been directed towards its inaccuracy, concerning descriptions of European art, history, architecture, and geography. As for Frater (2007), "the portrayal of the Priory of Sion as an ancient organization connected to goddess-worship is incorrect"(p. 2). The real Priory of Sion was founded in 1965 not in 1099, as claimed in the novel.

Toews (2003) proposes that The Da Vinci Code is two books in one, where the first one is a very skillful suspense novel and the second revolves around a religious belief that Jesus was married to Mary Magdalene. Dan Brown carefully creates two protagonists: Robert Langdon and Sophie Neveu. He creates them in such a way that it advocates his targets. Robert Langdon is an expert on religious symbology and a Harvard professor, while Sophie is a cryptologist and Parisian police agent. Both of them have skills which allow them to solve puzzles and Vol. 47 
mysteries. The novel was adapted to film by Columbia Pictures on May 2006. Tom Hanks acted as Robert Langdon. The film was attacked by the U. S. conference of Catholic Bishops for being morally offensive.

\section{Review of literature}

Based on critics' debates, stylistics is considered a controversial science, because it covers a wide range of approaches. "Style is a fuzzy concept that defies easy definition. We believe that we recognize style when we see it, but much of our intuition is based on vague and unanalyzed impressions"(Studer, 2008, p. 1). Stylistics is known as applying linguistic models to literary texts, but later this claim becomes evidently incorrect, because these models could be applied to any type of text, even if it is not a literary discourse. Stylistics includes theories that are related to pragmatics, psychology, and social theories.Gray (1994) argues that style is "the characteristic manner in which a writer expresses himself-or herself-, or the particular manner of an individual literary work"(p. 227). Verdonk (2002) proposes that stylistics is the analysis of distinctive expressions in language and the description of its purpose and effect.

Cognitive stylistics offers devices for studying different types of language, while applying these tools to literary works in specific is known as cognitive poetics. Cervel (2010) argues that cognitive poetics emerges as a powerful framework for the analysis of literary works because it "provides us with tools stemming from bodily experience which aims at universality"(p. 10). In William's (2012) contribution, cognitive poetics combines both the subjective and the universal interpretive strands into account, integrating them into a balanced analysis, where neither of them is privileged. Cognitive poetics makes use of cognitive 
sciences as a frame of reference, sciences like psychology, neuroscience, and semantics. It directs attention to innate brain processes. Cognitive poetics aims to neglect the individuality of both of the reader and the author, while the focus becomes on context. William (2012) considers cognitive poetics a pliant approach, where it is applicable to most literary genres. "Cognitive poetics not only integrates the universal and sociocultural factors of text production and reception, it also may be used productively in conjunction with other interpretive approaches"(p. 175). Gavins and Steen (2003) believe that there are two kinds of cognitive poetics. The first one relates to the rise of cognitive linguistics. Proponent of this kind are Turner, Lakoff, and Crisp. They focus on the possibilities for applying cognitive-linguistic metaphor research to cognitive poetics. The other kind of cognitive poetics is more oriented towards cognitive sciences. It contains works by psychologists like Oatley and Gibbs.

Stockwell (2008) considers Reuven Tsur (1992, 1998, 2008a) the founder of cognitive poetics. Tsur originates the phrase cognitive poetics in his book Toward a Theory of Cognitive Poetics in 1992. His works are part of a cognitive turn in arts, humanities, and social science research. He presents and outlines the beginning of a theoretical approach based on a wide range of interdisciplinary fields. Freeman (2009, p. 451) claims that Tsur's work stands between the establishment of Chomskian linguistics as a classical theory and the emergence of cognitive linguistics as a challenge to it. Fricke (2007) states:

So, we should not expect literary theory to yield anything fundamentally new in its own field: We will continue paraphrasing Aristotle's basic insights. I can see only one possibility for moving beyond what has long since been known: Inter-disciplinary engagement with the advancement of knowledge in other disciplines. At present, above all a new field has emerged only recently and consists of the 
philosophy of mind, psychological cognitivism, the effective sciences, cognitive linguistics, and neurological brain research- a cognitive turn to follow the linguistic one. ( p. 193)

Stockwell (2009) believes that cognitive poetics takes a lot of its approaches and models from diverse branches of cognitive sciences, but it is necessary at a certain point to realize that applying these tools to literary works changes their aspects, where cognitive poetics becomes marked by its own features. Stockwell determines some of these features which are experientialism, generalization, continuity, embodiment, and ecology. The notion of figure and ground is a basic concept in cognitive linguistics that is introduced by Talmy (2000). This theory has been tackled first by Koffka (1936), while he was presenting the principles of Gestalt psychology. He has proposed a certain feature that is known as duo formation, where figure appears to be in front of ground, and where figure is asserted by the properties of solidness and shape, while ground is loose and unshaped. This makes the figure better remembered. In a landscape such as a street, the sky is ground, while the houses are figures. Ehrenstein (2001) argues that ground is not necessarily behind figure. If we look through a window at a tree, the window screen appears as ground, while it is in front of the figure. As for Hirvonen (2013), each mind organizes its visual environment in different terms; it occurs individually. Moreover, figure and ground segregation of the visual fields is a dynamic event rather than static, where objects and surfaces are definable as figure and ground, depending on where one's attention is directed.

\section{Theoretical Framework: Text World Theory}

The present paper explores Dan Brown's The Da Vinci Code, while applying Gavins' (2007) text world theory. The argument is that Gavins' text world model is definitely convenient for the description of the way in which the discourse of the novel is 
processed in an exciting, creative, and dynamic way. The theory has been initially developed by Paul Werth (1994, 1995, 1999).Text world theory is a deictic discourse approach which intends to investigate the mental spaces that construct all spoken and written discourse. "Discourse is the conscious and common effort on the part of the maker and the receiver to make 'a world' wherein propositions are extended and embodied, and finally result in semantic structure"(Werth, 1995, p. 95). Like all cognitive linguistic approaches, in text world theory, context is central. It is introduced through the discourse-world level which includes the setting in which the discourse takes place, the participants, and the knowledge stored in the minds of the participants. According to Werth (1999), this knowledge consists of conceptual frames. These conceptual frames are used by participants when they communicate to create mental constructs or text-world representations. He states:

A world...is a conceptual domain representing a state of affairs, a text world, in particular, represents the principal state of affairs expressed in the discourse. First, the world must be defined: this is affected by means of the deictic and referential elements nominated in the text, and fleshed out from knowledge (specifically, knowledge frames). (1995a, p. 78)

Gavins' ( 2000, 2003, 2005, 2007, 2012) contribution is considered the most significant one. She introduces it as a model which "is based on the notions of mental representations found in cognitive psychology and which shares the experientialist principles of cognitive linguistics"(p. 8). Gavins assumes that it could be applied to any discourse, where the discourse is affected by social, historical, situational, and psychological factors. In Stockwell's (2002) account, text world theory gives answers to questions like "how the reader's vast background knowledge is specified for application in any particular context of reading"(p. 
135). Throughout her theory, Gavines introduces three distinct conceptual levels. The next diagram summarizes her concept.

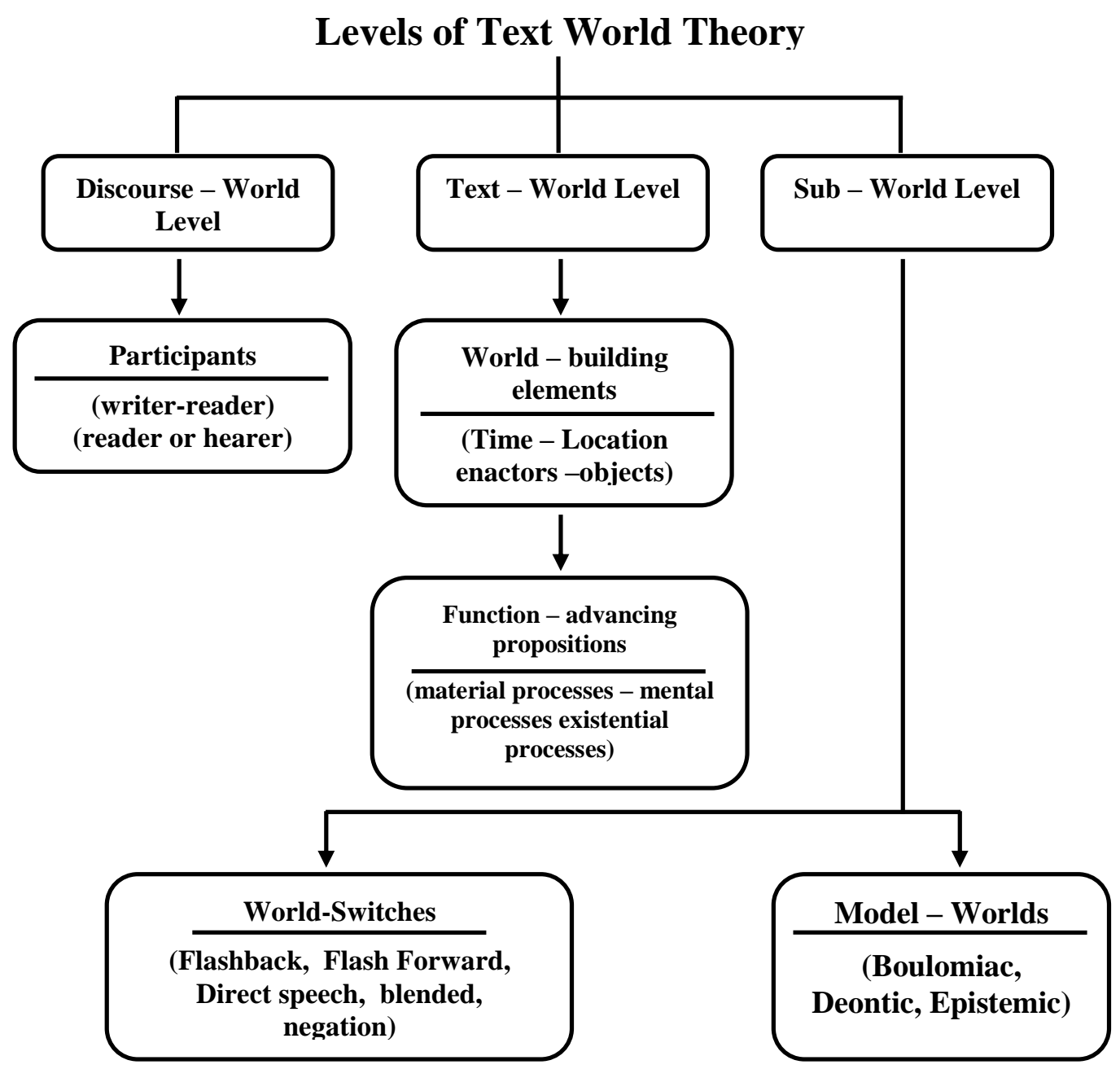

Figure 1

Figure.1. Levels of Gavins' text world theory. (My diagram)

The first level is called the discourse-world level. It deals with communication, so it needs two or more participants. Stockwell (2002) believes that this layer depends on "perceptions Vol. 47 
of present situation and beliefs, knowledge, memories, intention, and imaginations of the two participants"(p. 136). The next level is called the text-world level. In this level, the world-building elements are determined. The third level refers to the sub-worlds. Werth (1999) classifies sub-worlds according to their triggers like expression of beliefs or desires, metaphorical images, and flash-backs or flash-forwards. Gavins (2007) proposes only two categories which are world-switches and modal-worlds. Stockwell (2005, p. 140) divides the sub-worlds into three types, deictic sub-worlds, attitudinal sub-worlds, and epistemic subworlds. The next section separately discusses each level according to Gavins' classification.

As for Gavins (2007), communication happens only through a conscious act of human will. "Whenever we speak, listen, read, or write, we do so in the expectation that our co-participants are engaging with us in a mutual communicative endeavor"(p 20). In this case, a discourse-world comes into being, where the communicators become participants. There must be a purpose for communication whether to share, learn, argue, and so on. But, it is dominant that communication is a dynamic one, where meanings are not pre-determined. In text world theory, gaining knowledge is the central motivating factor behind all acts of communication. By incrementation, Gavins refers to the process where participants increment diverse knowledge structures. They can exchange facts, express emotions, argue opinions, or offer a point of view. "This transfer of knowledge from private to public ownership, which forms the primary basis of all discourse, is known as incrementation"(p. 21).

In written texts, the discourse-world becomes split, where the participants occupy separate spatial and temporal locations. The immediate environment becomes of secondary importance. There are other reasons for making the discourse split as in telephone conversation or recorded discourse. In written text, the discourse is split between the spatio-temporal environment of its Vol. 47 
author and the spatio-temporal environment of its reader. The only access of the reader to his co-participant (writer) is through the written text. In written text, a lot of real-world factors may affect understanding like the name of the writer, his gender, his age, his previous works, and his reputation in the wider community. "Varying degrees of this kind of experiential knowledge carry with them similarly varying expectations of how a new contact with the writer concerned is likely to develop"(Gavins, 2007, p. 27).

In text-world level, world-building elements and functionadvancing propositions are determined. In Gavins' (2007) account, our understanding of physical space and the progress of time affect our mental representations or the text-worlds we create in our minds in order to conceptualize the discourse. World-building elements are employed to set the spatial boundaries of the text-world. They locate the discourse in a particular place by using the deictic terms such as locatives (abroad), spatial adverbs (here), demonstratives (those), and adverbs of motion (come). We conceptualize all of these terms with reference to the origo which is known as I, here, now. In this level, Gavins discusses deixis which is the language that is used to express our position in the world and our relationships with the objects around us. It is limited to expressions of time and space. Deixis is "grammaticalisation and lexicalizations of referential information which is processed contextually"(Green, 1995, p. 12). According to Werth (1995, p. 65), deixis has two main components: spatio-temporality (locative information) and egocentricity (directional information). Gavins refers to a psychological process which is known as projection. In this process, participants construct a remote text-world. This world is different in its spatial and temporal parameters from the discourse-world. In text-world level, the participants in certain cases become enactors. As for Emmott (1997), the term enactors is better than character, because it can distinguish between 
Style and Cognition in Dan Brown's The Da Vinci Code Dr. Amira Abou Alam

different representations of the same character at different levels in narrative. She states:

Accessing information within the entity representation is more a matter of foregrounding one subset of information against another, rather than treating subsets as mutually exclusive. This foregrounding is complicated by the fact that in flashback a reader may have knowledge of what is to happen next, but must also judge events on the basis that the characters do not have this knowledge. (p. 181)

Any text-world begins to advance beyond its initial worldbuilders through some processes which are types of functionadvancing propositions. As for Gavins, these processes are material processes, mental processes, and existential processes. Material processes relate to actions or events in discourse. They are divided into two types: intention processes (as a result of an Actor's will), and supervention processes (there is no deliberate will). They are accompanied with a change in state or in relationships between text-world elements. Processes of perception and cognition like thinking and judging are considered mental processes. "Existential processes simply describe the existence of an element in a text-world (for example 'there is a garden')"(Gavins, 2007, p. 62).

Creating sub-worlds needs multiple mental representations, so that the discourse participants become able to construct these sub-worlds in their minds. Throughout her text world theory, Gavins (2007) explains the processes which enable human beings to manage several text-worlds at once. To establish a sub- world, there must be another tense and other time-zones are briefly visited. There must be a relation between each text-world's status and those which precede it. "Not all new text-worlds have an equal status in our minds and there are a number of reasons why we perceive some text-worlds to be more familiar, more trustworthy, more reliable than others"(Gavins, 2007, p. 76).

Vol. 47 
According to text world theory terms, a shift in time and location is known as world-switch. This shift emerges as a consequence of creating, for example, a flashback-world, a flashforward-world, a direct speech-world, a negated world, or a blended world. Any departure from the current situation is considered a world-switch. "In the course of processing textworlds and sub-worlds, participants (and characters) can switch backward and forth between worlds, a process called toggling"(Stockwell, 2002, p. 142). As for Emmott (1997) worldswitches mean that "the reader ceases to directly monitor one frame and starts monitoring another frame"(p. 147). Gavins (2007) introduces the concept of modality, where writers employ certain linguistic expressions to convey complex emotional states and feelings to the readers or the discourse participants. "Modality is the term given to those aspects of language which express a speaker or writer's attitude to a particular subject"(p. 91). Gavins divides modal-worlds into three types: boulomaic modal-worlds, deontic modal-worlds, and epistemic modalworlds.

\section{Data Analysis}

The discourse-world of The Da Vince Code is split between the spatio-temporal environment of its author and the spatiotemporal environment of its reader. The wide distribution of The Da Vinci Code means that there are many possible readers of the text and thus many possible environments. The only access of the reader to his co-participants (the author) is through the text which he is able to read thanks to the linguistic knowledge structures they share. Reader of The Da Vinci Code cannot really build his understanding of his co-participant's communicative purpose as in face-to-face communication. He does not know if the author wants only to entertain him, to teach him, or to document 
something. The author has something he wishes to communicate, and the reader is similarly engaged in a willful endeavor to understand him.

There are some real-world factors which might impact upon the reader's understanding of the discourse-world such as the real-world information about the author. Concerning the present research, these pieces of information are available for the reader, because Dan Brown is an outstanding character in his field. Through the media, the reader is able to recognize how the writer looks like, his age, and his previous literary works. These types of information facilitate the process of knowledge incrementation. "We may be familiar with the author named, either through personal contact, through exposure to their previous written work, or just through their reputation in the wider community"(Gavins, 2007, p. 27).The reader's knowledge about Dan Brown carries expectations about how a new work of him might be, because there are common characteristics of his style of writing and of the subjects that he tackles. These expectations affect how the reader perceives and evaluates his co-participant (the author) and the language he produces. On the other hand, there is no certain or ideal discourse-world participant in the mind of the author, in relation to his career and to his status as an international writer.

Reading the words of the title may have no immediate resonance for those who try to detect Brown's works for the first time, but regular readers of Dan Brown's works have the potential to extend beyond the simple comprehension of the title. Due to their experiential knowledge of similar titles like Angels \& Demons and The Lost Symbol, they are able to recognize some hints about the content of the novel. Brown is fond of classical and historical works and each time he intertwines them with detective incidents, where something new comes into being. This explains the presence of the great painter, Da Vinci, in the title of the book. Leonardo Da Vinci was an Italian polymath. He was Vol. 47 
perfect at painting, sculpting, science, music, engineering, botany, and a lot of other fields. The Mona Lisa is his most famous work, while The Last Supper, which is presented in the novel, is the most significance religious painting of all time. Also the word code adds rather more detail about the element of mystery and about the possibility of being a suspense novel. Relating the artist Da Vinci to the word code leads the coparticipants to assume that they must signify some kind of adventures which are related to the famous works of Da Vinci. The words of the title have an immediate sense and direct impact upon the regular reader's store of cultural knowledge. "Not only as things which I as an individual have seen before but as traditions carrying significance for the wider cultural community to which I identify myself as belonging" (Gavins, 2007, p. 29).

The Da Vinci Code is divided into 105 chapters, a prologue, and an epilogue. Most of them begin with a narrative description for the location and also for the enactors who inhabit the textworld. The setting of the novel is contemporary, and the story is narrated in the third person. The simple past tense is permanently adopted. To apply the two levels, some extracts are selected. Each extract is separately analyzed in the following section.

\section{Extract one}

In this extract, Jacques Sauniere, the renowned curator of the Louvre, is killed by someone because of a secret that Sauniere protects.

$$
\begin{gathered}
\text { Louvre Museum, Paris } \\
\text { 10:46 P.M. }
\end{gathered}
$$

1. Renowned curator Jacques Sauniere staggered through

2. the vaulted archway of the museum's Grand Gallery. He

3. lunged for the nearest painting he could see....Grabbing

4. the glided frame....Sauniere collapsed backward in a 
5. heap beneath the canvas...a thundering iron gate fell

6. nearby, barricading the entrance to the suite. The parquet

7. floor shook. Far off, an alarm began to ring. The curator

8. lay a moment...I am still alive. He crawled out...A voice

9. spoke..."Do not move"...He was broad and tall, with

10. ghost-pale skin..."Now tell me where it is"... "You and

11. your brethren possess something that is not yours"...How

12. could he possibly know this?..."Is it a secret you will die

13. for"..."I will tell you what you need to know"...The lie

14. he told was one he had rehearsed many times... "This is

15. exactly what the others told me"..."All three of them.

16. They confirmed what you have just said"...The attacker

17. aimed his gun again. "When you are gone, I will be the

18. only one who knows the truth"...If I die the truth will be

19. lost forever"...The curator looked down and saw the 20. bullet hole...As veteran of la Guerre d' Algeria, the 21. curator had witnessed this horribly drawn-out death 22. before....I must pass on the secret. (pp. 13-15)

In this prologue, the text-world is constructed around the Louvre museum in Paris. Although a precise year or day is not given, the time is provided (10:46 P.M.). Other world-building information in the text enable the reader to narrow the possibility for the temporal setting of the text-world to around the 1990s, 
information like the iron gate which falls with the ringing of the alarm. The enactors are Jacques Sauniere, three brethren, and a killer. The reader is immediately pushed into Sauniere's consciousness through the process of free direct thought. This is exemplified in the sentences which are put in italics in the original text like, "I am still alive" (line 7). This technique, which is employed by the writer to mark the working of the characters' mentality, is considered a graphological foregrounding. The description of the surroundings is evidently detailed by a series of world-building elements or deictic terms such as museum, Grand Gallery, nearest painting, thundering iron gate, parquet floor. Having visited museums before, the reader can strongly construct an image of The Louvre with its Grand Gallery, its paintings, and its safety procedures. Thus, the reader's personal knowledge in the discourse-world combines with the narrative description in the text-world. According to text-world theory terms, this process is known as projection, where the participants construct a remote text-world which does not correspond to the spatial and temporal parameters of the discourse-world. The participants are required to conceptualize a new deictic structure in which the origo (I, here, now) has shifted away from his sense of the here and now. What is common in literary discourse is that the readers become completely immersed in a particular textworld. "The projected deictic centre becomes the only means by which the temporal, spatial and social structure of the text can be understood" (Gavins, 2007, p. 41). Once the spatial and temporal location of the text-world has been established, the writer goes on to provide more detail about the museum. According to literary criticism, third-person narration always offers a less intimate relationship between the reader and the characters, in comparison with first-person narration. In this example, the scene is presented by a separate omniscient narrator, and in spite of this, the content of the text-world is focalized through Jacques Sauniere's perspective, especially through the sentences which 
are written in italics, and which refers to his mind's working as in saying, "I am still alive (line 7 )... How could he possibly know this?(line 11) ... If I die, the truth will be lost forever (line 18 )".

The spatial deixis of this text includes an initial definite reference to Jacques Sauniere, a less precise reference to the killer (through description), and a still further under-specific reference to your brethren or the others. It is evident that, through these diverse forms of presentation, Jacques Sauniere is the main focus of attention in the text-world, as he is the definite presence of the three. The others are ghostly semi-present in the text-world. The character of the killer is introduced without a name but only via physical description (He was broad and tall, with ghost-pale skin and thinning white hair. His irises were pink with dark red pupils). The writer presents a series of worldbuilding elements (Gallery, painting, gilded frame, canvas), where the precise spatial relationships between these items are set by a variety of spatial adverbs and other locatives like, the nearest, toward, beneath, far off, somewhere, and through. The conceptual structure of the opening of the novel is shown in the next figure. 


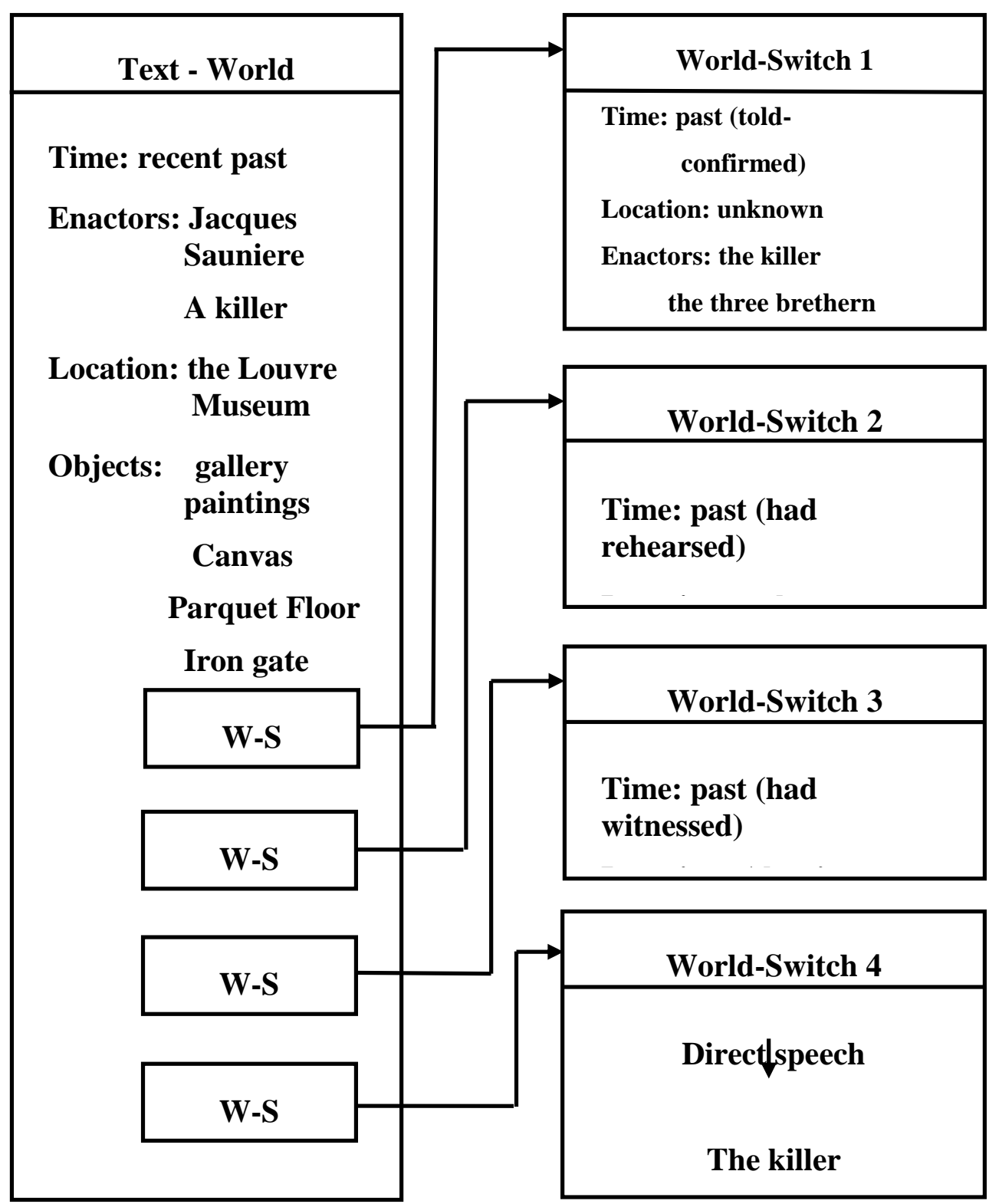

Figure 2

Figure.2. Text-worlds and world-switches of extract one. 
To the left of the diagram is the text-world created by the third-person, simple-past narration which makes up the majority of the extract, labeled in the diagram as text-world. Its time-zone is the recent past, and its enactors are Jacques Sanuiere and a killer. The setting of this text-world is the Louvre museum which contains gallery, paintings, iron gate, and other belongings. The ghostly figures of the three brethren or the others do not appear in this first text-world. Unlike Jacques and the killer, these enactors do not belong to the recent past time-zone, but rather seem to cross the temporal boundaries of the text-world. According to text world theory terms, referring to the others creates a world-switch into a new time-zone, labeled worldswitch 1. It is evident that it emerges from the initial text-world. World-switches make the reader aware of the presence of another temporal setting containing a different set of enactors.

Another time-zone is briefly visited, creating a worldswitch, when Jacques mentions that he had rehearsed a lie many times. The change in the tense of the passage from the simple past into the past perfect causes another shift in the temporal parameters of the text-world. This world-switch is labeled worldswitch 2. A third world-switch occurs later on the text, when Jacques remembers his memories in Algeria through the war. Another change in the tense from the past simple to the past perfect (had witnessed) causes another shift in the temporal parameters of the text-world. This world-switch is labeled worldswitch 3. World-switch 3 shifts the deictic center of the textworld from the narrow focus of Jacques in the museum to a much broader view of Algeria through the war. Flashbacks such as these examples are common causes of world-switches in literary narrative. Also direct speech may be a cause for world-switches. When direct speech, which is characterized by the inclusion of speech marks, occurs in a past tense- narration, such as that of the selected example, a shift in tense from past to present generates a new text-world. "Each time an enactor speaks, a Vol. 47 
world-switch transports readers of the text directly to that of enactor's origo for as long as the speech is ongoing"(Gavins, 2007, p. 50).

Another world-switch, which is labeled world-switch 4, is caused by the direct speech that is said by the killer: "When you are gone, I will be the only one who knows the truth (line 17)". There is a shift in time-zone and in the spatial location of the text. Readers must project themselves to the killer's origo in order to conceptualize how he sees his own future developing from this deictic point. In this case, readers become able to imagine an unrealized text-world, in which the killer's future beliefs are carried out.

\section{Extract Two}

Epistemic modality refers to some lexical verbs which express beliefs like suppose, believe, and know. There are also some adverbs which express epistemic commitment such as possibly, perhaps, and doubtfully. "The use of epistemic modality in discourse establishes a distinct text-world, an epistemic modalworld, containing a situation which may be unrealized at the time and place from which its description originates"(Gavins, 2007, p. 110). In this example, Teabing and Langdon are constructing some hypothetical situations to make Sophie convinced with their idea about the secret of Marry Magdalene's marriage to Jesus Christ, and how this is revealed via one of the most famous paintings of Da Vinci, The Last Supper.

1 Teabing's study was like no study Sophie had ever 2 seen..."Finally," Teabing said, "if you view Jesus and

3 Magdalene as compositional elements rather than as

4 people, you will see another obvious shape leap out at 5 you," He paused. "A letter of the alphabet"..."...If Jesus 
Style and Cognition in Dan Brown's The Da Vinci Code Dr. Amira Abou Alam

6 were not married, at least one of the Bible's gospels

7 would have mentioned it and offered some explanation

8 for his unnatural state of bachelorhood"..."...As any

9 Aramaic scholar will tell you, the word companion, in

10 those days, literally meant spouse"..."...And here too"

11 Langdon said, pointing....Sophie squinted and saw a

12 hand emerging from the crowd of disciples. "Is that hand

13 wielding a dagger?" "Yes. Stranger still, if you count the

14 arms, you will see that this hand belongs to...no one at

15 all. It is disembodied. Anonymous"..."...Her story is

16 everywhere once you open your eyes"..."...And if you

17 have ever seen any paintings by Georgia O'Keeffe, you

18 will know exactly what I mean".(p.323-39)

This extract is considered the essence of the novel for which Dan Brown is fighting. The hypothetical situations include a great deal of world building elements and function-advancing details. Some hypotheticals are actualized in the discourse-world containing Sophie, Teabing, and Langdon, and some are not. The hypotheticals are put in conditional constructions. According to grammatical rules, conditionals are divided into two components: the protasis and the apodosis. "The protasis is the part of the conditional which sets up a theoretical situation and marks it as remote from actuality....The apodosis component of the conditional, on the other hand, defines a situation which is consequent on the protasis"(Gavins, 2007, p. 120). The protasis 
establishes an epistemic modal-world which has its status as unrealized possibility. This is presented in sentences like, " if you view Jesus and Magdalene as compositional elements rather than as people (line 2)... if Jesus were not married (line 5)... as any Aramaic scholar will tell you (line 8)... if you count the arms (line 13)...once you open your eyes (line 15)... and if you have ever seen any painting by Georgia O'keeffe (line 16)". On the other hand, the apodosis component of the conditional includes the function-advancing information which takes the initial hypothetical situation to a further point or conclusion. This is exemplified in sentences like, " you will see another obvious shape (line 4)... one of the Bible's gospels would have mentioned it (line 6)...you will see that her story is everywhere (line 15)... and you will know exactly (line 17)".

The if clauses in the protasis section of the conditional generate an epistemic modal-world in which the hypothetical situations are presented. Teabing and Langdon go on to add more and more details to their imagined world, where Sophie becomes totally convinced with their idea about the holy blood, as mentioned in the text. Many of the recurrence of you will see and you will know are followed by the construction of an apparent future time-zone. These kinds of constructions hold a strong epistemic commitment on the part of the speaker to the functionadvancing propositions they include. Using If as a temporal deixis denotes the unrealized nature of the world, where the states being described have not yet come into being in the originating world. If helps the reader to realize the distance between the two worlds, the original and the imagined. Some protasis clauses include function-advancing processes as well as deictic world-builders like, for example, if Jesus were not married... as any Aramaic scholar will tell you... if you count the arms...and once you open your mind. These clauses contain material intention processes like counting, telling, opening, and marrying. The outcome of these processes is considered positive 
for the speaker, because Sophi will be convinced with the truth they believe in. In this example, there are two negated-worlds: The first is a syntactic negated one, while the other holds inside it a sense of negation. In saying, "if Jesus were not married", the speaker foregrounds a truth that is absent for Sophie, through the negative structure, and in saying, "if you have ever seen any painting by Georgia O' keeffe", the speaker forms a contrast between what she sees and what she must see. The speaker leads Sophie to make some inferences by employing these negatedworlds. These inferences are essential mechanisms for worldbuilding. Throughout making use of negation, the speaker is providing Sophie with a detailed and varied picture of his hypothesis to construct her own inferred representation. The conceptual structure of this extract is shown in the next diagram.

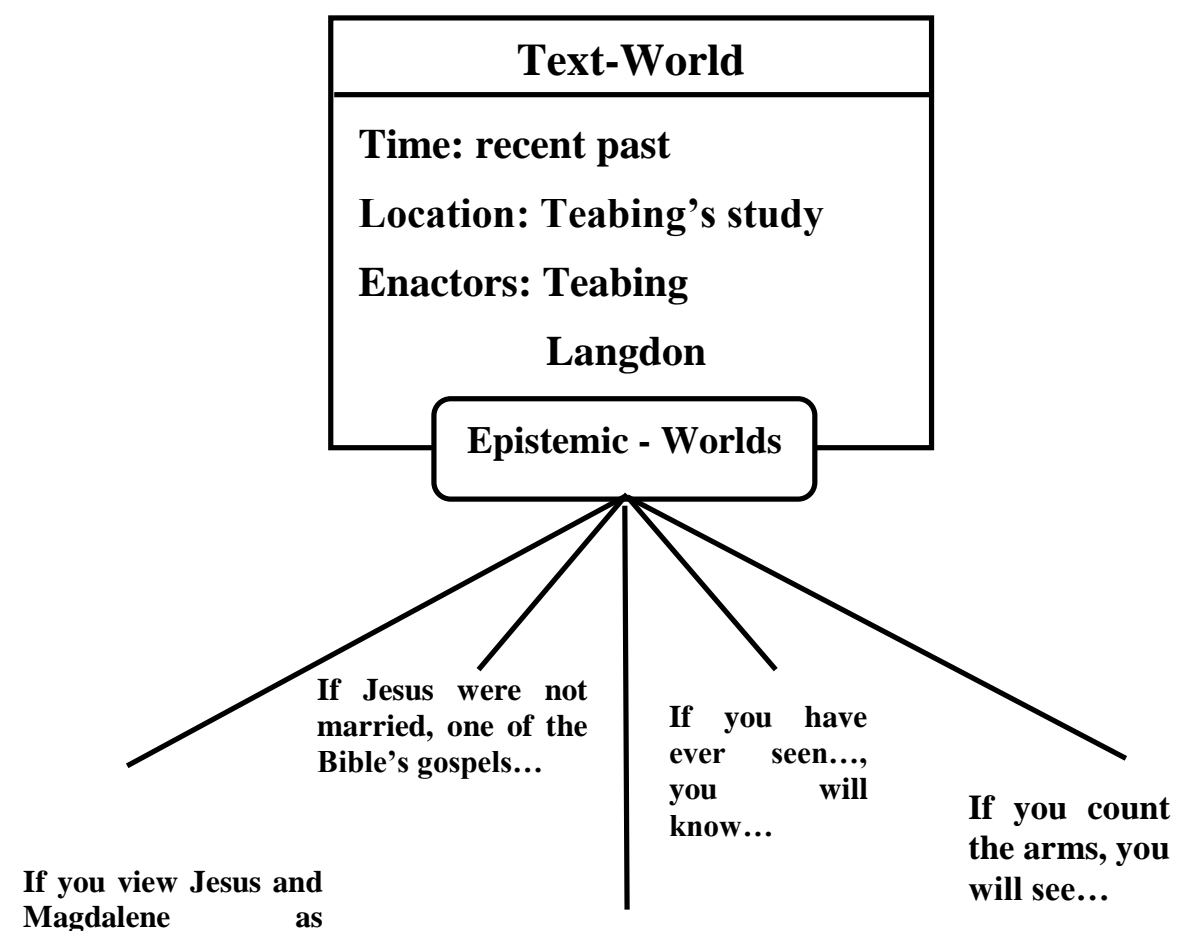

Magdalene as

Compositional..., you

will see...

Vol. 47
Once you open

eyes, her story is everywhere

Figure 3 


\section{Findings and Conclusion}

Through applying the first level of text world theory to the selected extracts, it becomes evident that the writer manages via the words, which are carefully chosen, to enable the intended audiences to construct a clear picture in their minds, in spite of being separated in both time and place from the text. However, according to text world theory perspective, each reader adds his own image, where part of the process of constructing mental picture is based on elements outside the text. Readers' understanding is partly built on their previous experiences. Nevertheless, a wide sector of the Arabic readers may find it complicated to add its own image, especially when the writer exaggerates in describing historical places. This is considered a cultural difference, and it makes the Western reader more communicative with these types of texts. Aside from the fact that the modern communication means, especially the internet, makes it possible for each one to detect every inch around the whole world. This is credible if the reader is attempting to make a research or looking for some information, but when reading a literary work, the reader seeks to enjoy. He wants to be able to imagine the places that the writer mentions, and his inability, which is a consequence of cultural differences, may affect his enjoyment in some way or another. In this vein, text world theory refers to the dynamism of the incoming information in order to be accommodated and comprehended. It considers understanding an act of negotiation in process, where meaning is not predetermined or fixed.

It is not evident if Brown takes into account the Arabic reader or not, but with no doubt, the Arabic reader lacks crucial knowledge about the historical places that are depicted in the two novels, and this might not help him to achieve an acceptable degree of communication. "Indeed, communication in general 
would be impossible without the human knowledge which enables both its production and comprehension"(Gavins, 2007, p. 21). Text world theory is context-sensitive, where the participants' background knowledge affects the communicative process. Of course, the context of the Western reader is completely different from that of the Arabic reader, so communication through the text between the Western reader and his co-participant (the author) is easier than in the case of the Arabic reader.

It is reasonable that Brown or any other writer cannot take into account all types of readers around the whole world. He writes in accordance with his own culture, and coping with the cultural differences is the responsibility of the reader. Definitely, the wide distribution of Brown's works proves the ability of the reader to accept these cultural differences, and this assures text world theory perspective that understanding is a process of negotiation. After finishing the targeted novels, the Arabic reader finds himself aware of a lot of information about the historical places in Europe through the process of incrementation, where he, as a discourse-world participant, increments a variety of different knowledge structures via the text. It is evident that the cultural differences, which exist between the participants (the writer and the reader) at the discourse world level, are partly due to the ideological differences. In the West, discovering the historical places is a decisive component of their beliefs, and it does not relate to the standard of life or the degree of education. Gaining knowledge is a fundamental activity for them. In Arabic countries, it is different, because the importance of acknowledging and detecting the historical places relates to certain social sectors, and the reader of Dan Brown's novels may be not one of them. These ideological differences interpret Brown's persistence to extend the description of what he considers is normal to be known for everyone. There is an ideological gap between the two participants if the reader is an Vol. 47 
Arabic one, while the writer is a Western one. Otherwise, Brown has something he wishes to communicate, and the Arabic reader decides to engage in a willful endeavor to understand him. 


\section{References}

Botting, F. (2001). Gothic. London: Routledge.

Brown, D. (2003). The Da Vinci Code. London: Bantam Press.

Cervel, S. (2010). Macbeth revisited: A cognitive analysis. In Metaphor and Symbol, 26, 1-22.

Ehrenstein, W. (2001). Perceptual organization. In International Encyclopedia of the Social \& Behavioral Sciences, 11227-11231.

Emmott, C. (1997). Narrative Comprehension: A Discourse Perspective. Oxford: Oxford University Press.

Freeman, M. (2009). Cognitive poetics. In Pragmatics and Cognition, 17, 450-457.

Fricke, H. (2007). Response: Theses on literary theory. In Journal of Literary Theory, 1, 192-93.

Gavins, J. (2000). Absurd tricks with bicycle frames in the text world of The Third Policeman. In Nottingham Linguistic Circle, 15, 17- 33.

Gavins, J. (2003). To much blague? An exploration of the text-worlds of Donald Bartheleme's Snow White. In Cognitive Poetics inPractice, $129-42$.

Gavins, J. (2005). Rethinking modality: A text-world perspective. In Journal of Literary Semantics, 34, 79-93.

Gavins, J. (2007). Text World Theory. Edinburgh: Edinburgh University Press.

Gavins, J. (2012). Leda and the stylisticans. In Language and Literature, 21, 345-62.

Gavins, J. \& Steen, G. (Eds.). (2003). Cognitive Poetics in Practice. London: Routledge.

Gray, M. (1994). A Dictionary of Literary Terms. London: Longman.

Green, K. (Ed.). (1995). New Essays in Deixis. Amesterdam: Rodopi. Vol. 47 
Haye, T. (2009). Jesus: Why the World is still Fascinated by Him. Canada: David Cook.

Hirvonen, M. (2013). Sampling similarity in image and language- figure and ground in the analysis of filmic audio description. In Sky Journal of Linguistics, 26, 87-115.

Koffka, k. (1936). Principles of Gestalt Psychology. London: Kegan Paul.

Rogak, L. (2005). The Man behind The Da Vinci Code-an Unauthorized Biography of Dan Brown. New York: Andrews McMeel.

Sayers, D. (1992). Introduction to the omnibus of crime. In Haycraft, H.

(Ed.). The Art of the Mystery Story: A Collection of Essays, 71-109.

New York: Carroll \& Graf.

Scaggs, J. (2005). Crime Fiction. London: Routledge.

Simpson, P. (2004). Stylistics: A Resource Book for Students. London: Routledge.

Stockwell, P. (2002). Cognitive Poetics: An Introduction. London: Routledge.

Stockwell, P. (2005). Texture and identification. In European Journal of English Studies, 9, 143-53.

Stockwell, P. (2008). Cartographies of cognitive poetics. In Pragmatics\& Cognition, 16, 587-598.

Stockwell, P. (2009). Texture- A Cognitive Aesthetics of Reading. Edinburgh: Edinburgh University Press.

Studer, P. (2008). Historical Corpus Stylistics. London: Continum.

Talmy, L. (2000). Toward a Cognitive Semantics. Cambridge: MIT Press.

Tsur, R. (1992). Toward a Theory of Cognitive Poetics. Amsterdam: Elsevier.

Tsur, R. (1998). Poetic Rhythm: Structure and Performance-An Empirical Study in Cognitive Poetics. Berne: Peter Lang. 


\section{Style and Cognition in Dan Brown's The Da Vinci Code Dr. Amira Abou Alam}

Tsur, R. (2008a). Deixis in literature, what isn't cognitive poetics? InPragmatics \& Cognition, 16, 119-150.

Verdonk, P. (2002). Stylistics. Oxford: Oxford University Press.

Werth, P. (1994). Extended metaphor- A text world account. In Language and Literature, 3, 79-103.

Werth, P. (1995b). 'World Enough and Time': Deictic space and the Interpretation of prose. In Verdonk, p. \& Webster, J. (Eds.). Twentieth Century Fiction: From Text to Context, 181-205. London: Routledge.

Werth, P. (1995a). How to Build a World. In Green, K. (Ed.). New Essays on Deixis: Discourse, Narrative, literature, 49-80.

Werth, P. (1999). Text Worlds: Representing Conceptual Space in Discourse. London: Longman.

William, J. (2012). Cognitive poetics and common ground in a multicultural context: The poetry of Zehra Cirak. In The GermanQuarterly, 173192.

\section{Databases and Websites}

Frater, J. (2007). Top Ten Errors of The Da Vinci Code. Retrieved from www.listverse.com./2007/09/02/top_10_errors_of_the_da_vincicode/html. Lattman, P. (2006). "The Da Vinci Code" Trial: Dan Brown's witness statement is a great read. Retrieved from http/www.blogs.wsj.com. Law/2006/03/14/html.

Toews, B. (2003). The Da Vinci Code. Retrieved from.http/www.curledup.Com/davinci/html. 